\title{
Changing Patterns of Marriage Courtship among the Hausas: The Case of Emerging Role of Marriage Brokerage in Contemporary Kano Metropolis
}

\author{
Mustapha Hashim Kurfi \\ Department of Sociology, Boston University, Massachusetts- U.S.A
}

Accepted: May 5, 2012 Published: June 13, 2012

Doi:10.5296/jsr.v3i1.1946

URL: http://dx.doi.org/10.5296/jsr.v3i1.1946

\begin{abstract}
This paper describes a number of significant alterations in the patterns of courtship among the Hausas of Northern Nigeria with specific reference to contemporary Kano Metropolis identifying some attending consequences. These changes affect personal choice preference in spouse selection, power of parents and relatives, the role of agency of marriage brokerage, the demands of the dating parties, and the expectations of the spouses prior and during courtships and marriages. The results of the changes are both positive and negative. On the one hand, the changes have opened avenues for match-makers popularly known as "Masu Dalilin Aure;" expanded the markets of mobile telecommunications industries; and increased the social capital of those in the communication business. On the other hand, there has been a decline in the role of parents as primary socializing agents; a disruption in the family ethos; high rates of divorce rates; increase in the number of unwanted pregnancies, abortions and throw-away children; and a rise in reported cases of delinquent behaviors. The paper posits that comprehensive studies that will explore the cost and benefit analyses of the institution of marriage brokerage need to be conducted in order to have a nuanced understanding of the phenomenon, as well as the trajectories of its dynamics.
\end{abstract}

Keywords: Courtship, Marriage Brokerage, Dalilin Aure, Social Change

\section{Introduction}

Among the Hausas ${ }^{1}$ of Metropolitan Kano as with many African communities, marriage is a

For the purpose of this paper, I am using Hill's (1972) conceptualization of the Hausa as a linguistic not ethnic term, and therefore refer to those who speak the Hausa language by birth. This is because, among other reasons, ethnic classifications are fluid according to the social context; Kano is the most densely populated Hausa land; and the dialect of 
highly valued milestone. It is a legitimate source of family and a building block of the Hausas. In addition, Yusuf (1975) argues that marriage among the Hausas is the backbone of socio-economic and political development. Thus, its progress and maintenance signifies harmony, while crisis and divorce in the family always signals dangers and insecurity in the society. The institution attracts so much attention by the prospective couples, their parents, relatives, friends, the clergy, and the authorities. Marriage involves series of character investigations, parental historical background, endorsement and acceptance; the involvement of parents and elders; and the hope that the married spouses would later reproduce for continuity. Culturally, it is believed among the Hausas that an average married person is responsible and treated with some respect. S/he is considered morally worthy and capable of being matured at least in mind. Marriage creates harmony among the different parties involved (the groom's and the bridal's relatives, clans, tribes, ethnic groups, races and in some instances dynasties- thereby solidifying relationships and sustaining peaceful coexistence. Each party respects the other based on certain rights and privileges It is assumed to be a life-time affair as against a one-time temporary or contract that only the couple agrees to terms with in a court of law. Marriage among the Hausas is therefore a process that involves many parties and different patterns which are relative and dynamic.

There is no lower or upper limit of the period by which the process of marriage courtship ${ }^{2}$ begins and ends among the Hausas, it nevertheless begins somewhere and ends elsewhere. For instance, it may officially begin with Tambaya "knocking at the door"- which means the person interested in the lady's hands in marriage seeks for the consent of the lady's parents. Once approved, the dating continues. Exchange of gifts occurs between the parties, which is an evidence of acceptance and goodwill. Tradition demands that the groom-to-be parents pay homage to the bride's parents with the presentation of some token as "material evidence' $\mathrm{Na}$ gani, Ina so. Sooner or later, Gaisuwar Uwa da Uba -certain homage accompanied with gifts set aside for the biological or social parents of the bride follows. The dowry and the bride's price usually come before or during the wedding but in some rare instances after the wedding. The thrust of this paper is to specifically periscope the emerging role of the Marriage brokerpopularly known as Mai Dalilin Aure (Mai singular, Masu plural).

Smith's (1952) study of Hausa Domestic Economy identifies Dillanci as one of the various craft specialism that had existed in Hausa societies since the time immemorial. He describes Dillanci as a type of commission selling by which the commission agents trade (buy or sale or both as the case may be) with another person's capital at the direction of the person in return for limited rewards. An interesting finding of Smith that is related to our topic of discussion is the fact that Dillanci was practiced by both men and women. Additionally, it signifies how the craft of agency or brokerage is historically relevant among the Hausas and

Kano is considered the moderate and acceptable in writing, speech, as well as international media broadcast.

Courtship as used throughout this paper represents the traditional dating period during when a couple dates, getting to know each other. It encompasses the period before, during, and after engagement but before marriage. It however does not include period after the marriage, in situations when the bride does not move to live with the groom. 
how it has transformed over time. Thus, smith's study was conducted before independence (sixty years ago), and we still find it relevant in the contemporary Hausa society. Scores of years after, Adamu (1978) traced the origin of Dillanci in Hausa society and categorized it into two: Dillanci for export trade (or long distance trading) Fatauci approved by the market officer Sarkin Kasuwa and Dillanci for subsistence commodities purely negotiated by the seller and the commission agents. Adamu (1978) further contended that though Kano was described by the nineteenth century travelers who saw the commercial emporium of Hausa land, it may not have held that position in the eighteenth century, especially before the outbreak of the Sokoto Jihad in 1804. Some of the major questions to ask include: how and why are there changes in these patterns and what are the consequences of the changes?

\subsection{Research Questions}

In line with the above therefore, this study asks the following research questions:

1. What are the emerging roles of the Marriage broker Mai Dalilin Aure in contemporary Kano metropolis?

2. What was the pattern of marriage courtship in Hausa society in the recent past?

3. How has the pattern changed over time?

4. What are the factors responsible for the changes?

5. What are the potential implications of these changes?

\subsection{Research Objectives}

The main aim of this study is to examine the emerging roles of the marriage broker Mai Dalilin Aure among the Hausas with particular reference to contemporary Kano metropolis. Specifically, the study aims to:

1. Trace the existing pattern of marriage courtship in Hausa society in the recent past;

2. Identify changes in the patterns of marriage courtship in the area of study;

3. Explore some of the factors responsible for the changes; and

4. Highlight some of the implications of the changes.

\section{Literature Review}

\subsection{Reflection on Marriage Courtship among the Hausas}

In the recent past, parents or relatives were responsible for identifying the "ideal" suitors through reference to families that were known to be of high moral status. That was a clear indication of the role of families in socialization and initiation of members into adulthood and future. Also, there were other avenues through which the suitors met and agree among themselves prior to presenting the matter to parents. Those include festive like Hawan Sallah, Ta-ku-tuha, Maukibi, Ajo, Sayen Baki, and Saukar Karatu, etc.; at other public places like 
hospitals, parks, restaurants, commuters, etc. But with modernity, there have been changes in the patterns of courtship among the Hausas of Metropolitan Kano. For instance, the proliferation of social networking services through websites like Face book, Twitter, To go, and Linked In, etc. have provided yet other channels of social utility that connect people with friends, relatives, and most particularly loved ones that are potentially married-partners. Also, visitation at boarding schools; meeting in tertiary institutions as course mates or members of coteries, training together at the National Youth Service Corps orientation camps or areas of primary assignment, at the labor market, or as colleagues, etc. But why should we care about the how, when, and where the prospective couples meet or who "engineers" or networks the marriage? In other words, studies like this can provide answer to the so-what question.

Coles and Mack (1991) argue that marriage among the Hausas is a microcosm of the wider universe. Wives and husbands represent distinct but independent domains. Each of spouses helps to fully socialize the children. As such, unlike the Western conception of marriage as an institution built on nuclear family, in the African, and specifically Hausa sense, marriage goes beyond a nuclear to the extended family and by implication community and society at large. By implication therefore, marriages have to be built on solid and reliable foundations as against fantasies, fancies, or passion. One of the implications of these is a significant alteration in the existing patterns of courtship and social relationships in the communities. Similarly, Russell and Lyster (1992) argued that a well enhanced and enriched courtship helps couples to have productive relationships that would ease transition from single to married life and above all, facilitates and establishes fruitful married life.

\subsection{The Emerging Role of Marriage Broker in Contemporary Kano}

Apart from parents, relatives, friends, and other avenues that the Hausas utilized to get suitors, there used to be the Dillaliya- a woman who goes from house-to-house selling clothes, shoes, jewelries and other house items. The items were either new or used depending on whatever was available. The Dillaliya was performing another function which was to link suitors. After she might have gone into a household and realized that there was an unmarried lady, she would seek for relevant information and possibly collect the lady's picture. The Dillaliya upon, arriving another household sometimes at a distant area would advertize the goods that she carried and then opened a chapter of discussion with reference to and in favor of the lady whose photograph would be made available on demand. She would have many photographs of women seeking men to marry but could tactfully introduce the discussions and evidence only when "appropriate." Thus, the Dillaliya was multipurpose, providing series of services including selling new and used goods, exchanging goods for other goods; and above all, linking suitors in disguise.

That was the case of Dillaliya. As for Mai Dalilin Aure, his strategies and methods of operation are very different in many senses. Mai Dalilin Aure takes his job of marriage brokerage with all seriousness not under cover. Thus, he takes marriage brokerage to be a profession worthy of publicly practiced and making a living out of it. Thus, Sociologists or 
specifically Structural Functionalists would argue that while the Dillaliya's action towards marriage arrangements was the latent function of her actions, Mai Dalilin Aure's actions are manifest actions. Merton (1973) made a distinction between the particular purposes or interest of a human action (as manifest), and some unintended or unique advantages, which are not limited to conscious or explicit purpose (as latent). According to the theory, the manifest function of human actions is the observed or intended result of an action while the latent function is the unintended or unrecognized result. In other words, with reference to marriage brokerage in this context, the manifest functions are those actions that are known, seem to be obvious, and intended by the actors or participants as in the case of Mai Dalilin Aure. What then are the emerging roles of Mai Dalilin Aure?

The Marriage broker Mai Dalilin Aure plays a number of roles including the following:

1. Helps in identifying both men and women who seek for the opposite sex and who are interested in marriage. This covers a wide range of suitors at different categories: men and women- spinsters, bachelors, divorcees, widows, separated, bachelors, and those interested in increase in the number of wives (polygamous).

2. Mediates and negotiates among suitors. Mai Dalilin Aure is an intermediary between the both parties as he connects suitors and ensures that mutual understanding persists between them. In the event of misunderstanding, he amicably settles the conflict that arises.

3. Retains the known reputation of women in the community by tactfully and skillfully introducing ladies to potential male suitors in a manner that is not self-imposing. Traditionally, the Hausa women are required to live with certain degree of pride and self-worthiness. Men are usually required to say they love women and not the other way round. Nevertheless, there are "advances" that the women could sometimes make. The marriage broker performs this function by brilliantly "match-making" and gaining recognition and reward from one or both parties.

4. Helps in reducing the number of unmarried men and women in the society. By extension and implication therefore, the marriage brokerage as a professional industry plays a decisive role in reducing the number of unmarried persons notably divorcees; and reduces the number of unwanted pregnancies, abortions, thrown-away children, and widespread of diseases especially sexually transmitted diseases (STDs).

5. Creates jobs for himself and his subordinates/partners who are constantly trained to acquire the necessary skills required to promote the expertise. Marriage brokerage as a professional body recruits, trains, and utilizes an array of people ranging from informants, "Ice breakers," gatekeepers, suppliers of logistics like photographs, and contacts of certain target clients.

At this juncture, one might ask "What are the factors that contributed to the emergence of Marriage Brokerage in metropolitan Kano?" Certainly, there are many factors that triggered the emergence and facilitated the roles of Mai Dalilin Aure in particular and the institution or profession in general. To begin with, it is evident that there is an increase in the number of both men and women that are in need of marriage. Kano is the most densely populated state 
of the Nigeria with over 14 million people out of the 156 million as projected by the National Population Commission (2011). Thus, urbanization- specifically population explosion has facilitated the emergence of the organization of marriage brokerage. Young girls (spinsters) are seen in every corners of the city: boarding and day schools, ceremonies, markets, and other social gatherings. Some of them have the desire to delay marriage until after university education- thereby increasing the age at which they marry compared to what was obtained in the past.

Apart from the young unmarried girls that are in hundreds of thousands, there is a significant number of widows who lost their husbands as a result of natural death or diseases, ethnic, socio-religious crisis, or accidents. In a study by Kurfi (2010) it was revealed that most of such widows do not easily remarry due to fear of stigmatization, burden of taking care of orphans, and in some instances the widespread of diseases (notably sexually-related). This now creates another category of women seeking for re-marriage and thereby soliciting the services of the marriage brokerage industry.

Related to the above is a very high rate of divorce among the Hausas, especially in contemporary Metropolitan Kano. Findings of the All Africa Newspaper (2007) revealed that there was a high rate of divorce in Kano due to illiteracy, materialistic tendencies from the married women, impatience with co-wives, immaturity of some young girls, and the desire for some women to negotiate work at the expense of marriage. Other factors include the women's parents' lust to exploit the male suitors, thereby giving out the daughters' hands in marriage to old but rich men who are not compatible with the daughters. In addition, the findings identified unemployment and economic hardship as major forces that lead to increase divorce rates among the Hausa communities of Kano. One of the implications of the above is resorting to Masu Dalilin Aure to assist then in getting the right suitors for remarriage. Another way to ease getting remarried is through forming associations for the divorcees in order to collectively pursue their interests.

To buttress the above postulate, the Nigerian Village Square (2009) reported that there were 45,000 divorced women under the auspice of "Voice of Widows, Orphans and Divorcees Association of Nigeria" (VOWODAN) who demonstrated on the streets of Kano. The association had a grand plan to stage a one-million man march against increasing spate of divorce in the Kano but the police and other security agencies, including the State Security Services received a series of petitions from elders and religious leaders in the state who expressed the fear that the protest might snowball into a big crisis if allowed to take place. Hajia Altine Abdullahi is the Chief Executive Officer of VOWODAN and was pressured to drop the idea. She agreed on security reasons but the group had drawn attention to one of the biggest social problems confronting the core North today. Writing in the end of the 70's, Jackson (1978) wondered and asked Why Hausa women of Kano went on strike as a response to exploitation by a foreign capitalist enterprise but were incapable of such action in their relations with Hausa peasants. What take-home would he make out of the women's action on marriage-related matters? I guess this clearly indicates the magnitude of divorce as a social 
problem as well as the potentiality for the marriage brokerage industry to thrive.

In response to the above, the Kano State Hisbah board plans to arrange for the re-marriage of one thousand divorcees at the same time in an August event ${ }^{3}$. The bbchausa.com $\left(10^{\text {th }}\right.$ February, 2012) has organized a debate in its weekly Ra'ayi Riga inviting the chairperson of the VOWODAN, the chairman of the Hisbah Commission- Sheikh Aminu Ibrahim Daurawa, and other phone callers to the program. It was unanimously agreed that the rate of divorce was at alarming and on the increase and that there was the need for the government and all stakeholders to put all hands together to genuinely address the problem. In his remarks, the Hisbah board chair mentioned Masu Dalilin Aure as partners in identifying, networking, and assisting in the organizing of the marriages that the board intends to join.

Indeed, the Shari'a reimplementation in Kano state and many parts of the North threatened many unmarried women especially commercial sex workers (CSW) and drifted them into seeking for marriage partners. One of the easiest, safest, and convenient ways for this category of women to get suitors is through Mai Dalilin Aure. This however does not suggest that the activities of the CSW has drastically been reduced by the reimplementation of the Shari' $a$ rather to illustrate that it has contributed in triggering the emergence of, patronage and boosting of the marriage brokerage industry.

\subsection{The Future of the Marriage Brokerage Market in Contemporary Kano}

At this juncture, it will be too early for one to conclude that marriage brokerage market is absolutely positive or negative on the moral, social, political, and economic institutions of the Hausas. Weisner and Bradley (2007) observe that, generally as a global phenomenon, African family groups are becoming internally deinstitutionalized, carrying out fewer traditional functions, and becoming smaller and more unstable, and that the cultural value of familism weakens. They further contend that the African family is in crisis and has changed dramatically not for the better. But their analysis was only concerned about the declining or incomprehensiveness of the extended family and not exploring the aftermaths of the situation, including the emerging role of the brokerage market.

Oluwatoyin (1998) laments that in Nigeria the traditional peasant-style of marriage and family grouping have changed to new forms thereby affecting relationships and power relations both within and outside the home. In other words, there is a gap between the ideal and the obtained, subsequently leading to the emergence of new patterns of courtship, marriage, residential arrangements, and the totality of relationships. Solivetti (1994) attributes the changes in Nigerian family system, especially the Hausas' to the shift from the traditional agricultural, collectively pursuit economy to an alien, individualistic, incompatible "industrialized" economy. This shift, the author argues, has affected the efficacy and

It is striking to know that the chairperson of VOWODAN is among the first batch of the divorcees that are to be re-married through the above program as proposed by the Hisbah Board. 
comprehensiveness of the traditional family values. The above shows that the change is detrimental to the rich African traditional family system. It is against this background that this paper argues there is great challenge to the family, community, society, and stakeholders including researchers, calling for careful study of the changes in these patterns for policy implementation.

Future researchers should therefore examine the efficacy or otherwise of the marriage brokerage. This could be done in a number of ways including comparing marriages that Masu Dalilin Aure connected and others that were not connected by the same persons with a view to measure the impacts at comparative level. There is also the need to further explore and examine the efficacy or otherwise of the various techniques, methods, tactics, and strategies that the Masu Dalilin Aure adopt in networking (including identifying, connecting, and reunion)? What role do they play when relationships break up or down, and how? In terms of the economic dimension of the profession, how does it operate: how much or what percent does a party connected give as commission? Are there conditions that are attached to the services that the Marriage Brokers provide? How do they apply? In terms of period, when did the practitioners start and how? These and more questions need to be explored by future researchers.

\section{Conclusion}

This paper has described a number of changes in the patterns of marriage courtship among the Hausas of Kano with particular focus on the role of Mai Dalilin Aure. Among other things, evidence has been presented for an increase in the demand for marriage as a result of population density, rising age at marriage among spinsters, personal choice preference in mate selection, increase in the number of widows and divorcees, economic hardship, the reintroduction of Shari'a in the North and Kano state in particular, and importantly weakness in the traditional family values. These together led to the emergence of the marriage brokerage as a profession that is publicly and proudly practiced. Mai Dalilin Aure plays many roles including assistance in identifying appropriate suitors and thereby reducing the number of unmarried persons in the communities; mediating, regulating and in some instances settling disputes among the suitors; and economically providing job opportunities to the teeming unemployed as well as contributing to making and developing the marriage brokerage industry into professionalism.

\section{References}

Adamu, A. (1978). The Hausa Factor in West African History. Zaria: Ahmadu Bello University Press.

Coles, C. and Mack, B. eds. (1991). Hausa Women in the Twentieth Century. Wisconsin: The University Press. 
Hill, P. (1972). Rural Hausa: A Village and a Setting. Cambridge: University Press.

Jackson, S. (1978). Hausa Women on Strike. In Review of African Political Economy, No. 13, pp. 21-36. Also available online through subscription at: http://www.jstor.org/stable/3997976

Merton, R. K. (1973): Social Theory and Social Structure, Revised Edition. London: Collier Macmillan Publishers.

Oluwatoyin, I. (1998). The changing pattern of family structure in Nigeria: Issues, Problems and Strategies for Family Support. In Eekelaar, J. and Thandabantu, N.'s (Eds.). The Challenging Family: Family Forms and Family Law. Oxford: Hart Publishing.

Russell, M. N. and Lyster, R. F. (1992). "Marriage Preparation: Factors Associated with Consumer Satisfaction." In Family Relations, Vol. 41, No. 4. Pp. 446-451. Published by the National Council on Family Relations. Also available through subscription at: http://www.jstor.org/stable/585589.

Solivetti, L. M. (1994). "Family, Marriage and Divorce in a Hausa Community: A Sociological Model." In Africa: Journal of the International African Institute, Vol. 64, No. 2, pp. 252-271.

Smith, M. G. (1952). "A Study of Hausa Domestic Economy in Northern Zaria." In Africa: Journal of the International African Institute, Vol. 22, No. 4, pp.333-347. Also available through subscription at: http://www.jstor.org/stable/1156917

Weisner, T. and Bradley, C. (2007). "Crisis in the African Family." In Weisner, T., Bradley, C. and Kilbride, P. (Eds). African Families and the Crisis of Social Change. London: Bergin and Garvey Press.

Yusuf, A. B. (1975). "Capital Formation and Management among the Muslim Hausa Traders of Kano, Nigeria.” In Africa: Journal of the International African Institute, Vol. 45, No. 2, pp. 167-182. University Press: Cambridge.

\section{Website}

All Africa.com Newspaper Dec. 27, 2007. Also available online through: http://allafrica.com/stories/200712270305.html

The Nigerian Village Square (2009). Available online through: http://www.nigeriavillagesquare.com/forum/main-square/32900-women-agony.html

The bbchausa.com Weekly program Ra'ayi Riga $10^{\text {th }}$ February, 2012. Available online through: http://www.bbc.co.uk/hausa/interactive/2012/02/120210_raayiriga_zaurawa.shtml 
